\title{
PSYCHOLOGICAL IMPACTS AMONG PATIENTS WITH TYPE 2 DIABETES MELLITUS: A CROSS SECTIONAL STUDY
}

\author{
Sivaraman Subramanian1, Aarthi Rajarajacholan², Kaviyarasan Senguttuvan³, Ismail Mohamed4, \\ Thirumalaikolundusubramanian Ponniah ${ }^{5}$ \\ ${ }^{1}$ Associate Professor, Department of Psychiatry, Chennai Medical College Hospital and Research Centre, Chennai. \\ ${ }^{2}$ C.R.R.I, Chennai Medical College Hospital and Research Centre, Chennai. \\ ${ }^{3}$ C.R.R.I, Chennai Medical College Hospital and Research Centre, Chennai. \\ ${ }^{4}$ Research Co-ordinator, Chennai Medical College Hospital and Research Centre, Chennai. \\ 5 Professor, Department of Medicine, Chennai Medical College Hospital and Research Centre, Chennai.
}

\section{ABSTRACT}

\section{BACKGROUND}

People with diabetes experience higher rates of psychological disorders like depression, anxiety, eating disorders, phobias, adjustment disorders, substance use, psychotic and bipolar disorders and sexual dysfunction. The most common diagnoses among them being depression and anxiety. The aim of the study is to compare the level of anxiety and depression among diabetic and nondiabetic healthy population and to assess the level of distress and functional level in terms of self-care among the diabetic population.

\section{MATERIALS AND METHODS}

A semi-structured pretested questionnaire was used to assess the socio-demographic profile, Morisky Medication Adherence Questionnaire to assess the level of treatment adherence of the diabetic population, Hospital Anxiety and Depression Scale (HADS) for comparing the level of anxiety and depression between the diabetic and normal subjects and the Diabetes Distress Scale (DDS) and the Diabetic Self-Care Activities questionnaire (SDSCA-Summary of Diabetes Self-Care Activities) to assess the level of distress and functional level in terms of Self-Care among the diabetic population were used respectively.

\section{RESULTS}

The diabetic population had increased levels of depression than anxiety, which was found to be statistically significant. Based on the Diabetes Distress Scale, most of them had emotional distress of clinical attention and emotional distress. Based on the Summary of Diabetes Self-Care Activities Scale, most of the diabetics did not opt for a strict diet or exercise plan, blood sugar testing or foot care.

\section{KEYWORDS}

Psychological Problems, Type 2 Diabetes Anxiety and Depression Scale.

HOW TO CITE THIS ARTICLE: Subramanian S, Rajarajacholan A, Senguttuvan K, et al. Psychological impacts among patients with type 2 diabetes mellitus: a cross sectional study. J. Evolution Med. Dent. Sci. 2016;5(42):2634-2640, DOI: $10.14260 /$ jemds/2016/616

\section{INTRODUCTION}

Quality of life is diversely compromised in diabetes mellitus as in other chronic diseases and has an important impact on patient's daily life. Living with diabetes provides a daily challenge, as its management requires frequent and continuous effort from the person living with the condition. The co-morbidities associated with type 2 diabetes mellitus are categorized into the following groups: (1) cardiovascular; (2) hypertension; (3) locomotors morbidity; (4) psychosocial problems (Depression, anxiety, bereavement); (5) eye diseases (Cataract, retinopathy); (6) cancer; and (7) pulmonary morbidity (Asthma, COPD). ${ }^{1}$ The persons with Diabetes Mellitus must incorporate lifestyle changes in careful dietary planning, eventual use of medication and

Financial or Other, Competing Interest: None.

Submission 12-04-2016, Peer Review 07-05-2016,

Acceptance 12-05-2016, Published 26-05-2016.

Corresponding Author:

Sivaraman Subramanian,

\#1-1355 d, First Floor,

Vasannagar 15th Cross,

Vayalur Road,

Trichy-20.

E-mail: sivaramanaiims@gmail.com

DOI: $10.14260 /$ jemds/2016/616 regular blood glucose monitoring which are usually difficult for most of the patients and impose a psychological burden on them. ${ }^{2}$

Diabetes mellitus places serious constraints on patient's activities and it also permanently changes a patient's life causing a number of psychological, emotional, social and psychosexual problems and conflicts affecting their quality of life. ${ }^{3}$ Psychological stress factors in turn play an active role in both the aetiology and the metabolic control of diabetes mellitus. ${ }^{4}$ The economic and social costs of diabetes are enormous by both means, i.e. through loss of productivity and health care services.

People with diabetes experience disproportionately high rates of psychological disorders like depression, anxiety, eating disorders, phobias, adjustment disorders, substance use, psychotic and bipolar disorders and sexual dysfunction. The most common diagnoses among them being depression and anxiety. ${ }^{5}$ The DAWN (Diabetes Attitudes, Wishes and Needs) study results showed that as many as $41 \%$ of the Type 2 Diabetes Mellitus patients had poor psychological wellbeing. ${ }^{6}$ Review of literature revealed that when compared to the general population psychiatric disorders, depression and anxiety in particular are more frequent in diabetic patients. 7,8 Hence, this study was taken up to know the psychological 
status of Type 2 diabetic patients with that of normal individuals among patients attending a Tertiary Care Medical College Hospital in Tamilnadu.

\section{MATERIALS AND METHODS \\ Study Site}

This cross sectional observational study was carried out in the Department of Psychiatry along with the Department of Medicine of a Tertiary Care Medical College Hospital located in a rural area of Trichy District, Tamil Nadu, India between the months of June and July 2014.

\section{Sample Collection}

Subjects were taken up for this study by convenience sampling method.

\section{Inclusion Criteria}

The subjects who were included in this study were fifty type 2 Diabetes Mellitus patients free from any overt complications who attended the Diabetic review OPD and fifty normal subjects. Both male and female subjects aged between 25 and 65 years were included in this study.

\section{Exclusion Criteria}

People aged more than 65 years, those with severe medical illness, those who did not give the consent, those diagnosed to have psychiatric illnesses before diagnosed to have diabetes mellitus and those who use other psychoactive substance in a dependent manner were excluded from the study.

\section{Institutional Ethics Committee Clearance}

The study was approved by Institutional Ethics Committee and informed consent was obtained from each individual.

\section{Method of Study}

A semi-structured pretested questionnaire was used to assess the socio-demographic profile. The level of treatment adherence of the subjects with diabetic medication was assessed by Morisky Medication Adherence Questionnaire. ${ }^{9}$ which consists of 8 items. The Hospital Anxiety and Depression Scale (HADS). ${ }^{10}$ comprising of 14 items was used for comparing the level of anxiety and depression between the diabetic and normal subjects. The level of distress of the subjects with diabetes was assessed by the Diabetes Distress Scale (DDS). ${ }^{11}$ which covers 17 potential problem areas. The Diabetic Self-Care Activities questionnaire (SDSCA-Summary of Diabetes Self Care Activities). ${ }^{12}$ was used to assess functional level in terms of diet, exercise, blood sugar testing and foot care.

The instruments used to find out the difference between type 2 diabetics and normal subjects were all scalable measurements. The descriptive data of the sociodemographic data obtained was presented as mean \pm standard deviation with the ranges given within brackets and the descriptive data for that of the HADS, DDS and SDSCA scales are presented as the number and percentage of subjects who reported to have such complaints when interviewed with the respective scales. Pearson Chi-Square test, Unpaired t test and Mann-Whitney test were employed to find out any significance in the anxiety and depression levels between the two groups considering the normal subjects as control group and the diabetics as experimental group. Observations of normal subjects and diabetics are combined, grouped and then ranked for analysis. The data were analysed by computing the data in the SPSS version 21 software.

\section{RESULTS}

In this study group, 50 diabetics (25 males and 25 females) and 50 normal subjects (25 males and 25 females) were included. The socio-demographic profile of the study group is incorporated in Table 1.

\begin{tabular}{|c|c|c|c|}
\hline $\begin{array}{l}\text { Sl. } \\
\text { No. }\end{array}$ & $\begin{array}{c}\text { Socio-Demographic } \\
\text { Data } \\
\end{array}$ & Non-Diabetic & Diabetic \\
\hline \multirow[t]{5}{*}{1} & Age & & \\
\hline & Mean Age & 44.12 & 53.98 \\
\hline & Standard Deviation & \pm 14.346 & \pm 8.392 \\
\hline & Minimum Age & 25 & 31 \\
\hline & Maximum Age & 65 & 65 \\
\hline \multirow[t]{3}{*}{2} & Gender & & \\
\hline & Female & 25 & 25 \\
\hline & Male & 25 & 25 \\
\hline \multirow[t]{6}{*}{3} & Marital Status & & \\
\hline & Single & $28 \%$ & $10 \%$ \\
\hline & Married & $66 \%$ & $90 \%$ \\
\hline & Separated & $0 \%$ & $0 \%$ \\
\hline & Divorced & $0 \%$ & $0 \%$ \\
\hline & Widowed & $6 \%$ & $0 \%$ \\
\hline \multirow[t]{4}{*}{4} & Geographical Status & & \\
\hline & Urban & $4 \%$ & $4 \%$ \\
\hline & Semi urban & $12 \%$ & $8 \%$ \\
\hline & Rural & $84 \%$ & $88 \%$ \\
\hline \multirow[t]{8}{*}{5} & Educational Status & & \\
\hline & Professional course & $14 \%$ & $0 \%$ \\
\hline & $\begin{array}{l}\text { Post Graduates and } \\
\text { Graduates }\end{array}$ & $16 \%$ & $2 \%$ \\
\hline & $\begin{array}{l}\text { Intermediate and Post } \\
\text { High School Diploma }\end{array}$ & $8 \%$ & $8 \%$ \\
\hline & High School & $4 \%$ & $18 \%$ \\
\hline & Middle School & $24 \%$ & $40 \%$ \\
\hline & Primary School & $8 \%$ & $8 \%$ \\
\hline & Illiterate & $26 \%$ & $24 \%$ \\
\hline \multirow[t]{8}{*}{6} & Occupation & & \\
\hline & Professionals & $26 \%$ & $0 \%$ \\
\hline & Semi Professionals & $0 \%$ & $2 \%$ \\
\hline & $\begin{array}{c}\text { Clerical, Shopkeeper, } \\
\text { Farmers }\end{array}$ & $0 \%$ & $18 \%$ \\
\hline & Skilled & $16 \%$ & $6 \%$ \\
\hline & Semi-Skilled & $44 \%$ & $26 \%$ \\
\hline & Unskilled & $8 \%$ & $6 \%$ \\
\hline & Unemployed & $6 \%$ & $42 \%$ \\
\hline \multirow[t]{6}{*}{7} & $\begin{array}{c}\text { Income Status } \\
\text { [Monthly] }\end{array}$ & & \\
\hline & Rs $1000-5000$ & $10 \%$ & $34 \%$ \\
\hline & Rs 5001-10000 & $48 \%$ & $58 \%$ \\
\hline & Rs $10001-15000$ & $42 \%$ & $8 \%$ \\
\hline & Monthly mean Income & Rs- 8000 & Rs-6880 \\
\hline & Standard Deviation & \pm 3094.696 & \pm 14057.201 \\
\hline
\end{tabular}

The duration of diabetes in the diabetic subjects ranged from 1 to 780 weeks with a mean of 227.26. All the diabetic subjects were on anti-diabetic measures and about $62 \%$ and $54 \%$ of the diabetic subjects followed diabetic diet and regular aerobic exercises respectively.

Based on the Morisky Medication Adherence Questionnaire, we identified that $40 \%$ of the diabetic subjects sometimes forget to take the medicine. Among them $68 \%$ had 
missed taking the medicine over the past 2 weeks, $8 \%$ of them had cut back the medicine without telling the doctor as they felt worse when they took it, $16 \%$ of them forgot to take along with them the medicine while travelling and $10 \%$ of them did not take all the medicine the previous day. About $24 \%$ of the diabetics had stopped taking the medicine as they felt that their symptoms were under control, $48 \%$ of them felt that taking medicine every day is inconvenient to them and also felt hassled about sticking to the treatment plan; $32 \%$ of the diabetics never or rarely felt any difficulty in remembering to take all the medicine and the rest found it difficult once in a while sometimes, usually or all the time;
$60 \%$ and $40 \%$ of the diabetics belonged to the low and moderate category of treatment adherence respectively based on the Morisky Medication Adherence Questionnaire.

Descriptive statistics for the variables of the Hospital Anxiety and Depression Scale (HADS) are presented in Table 2. Based on the HADS Scale to assess the level for anxiety and depression between the diabetic and the normal subjects, the prevalence of depression was found to be higher in the diabetic subjects (82\%) when compared with the normal subjects (34\%) and this difference was found to be statistically significant using the unpaired t test, Pearson ChiSquare test and the Mann-Whitney test $(\mathrm{p}<0.05)$.

\begin{tabular}{|c|c|c|c|c|}
\hline Sl. No. & Question of HADS & Response & $\begin{array}{c}\text { Diabetics } \\
\mathbf{n}=\mathbf{5 0}\end{array}$ & $\begin{array}{c}\begin{array}{c}\text { Normal Subjects } \\
n=50\end{array} \\
\end{array}$ \\
\hline \multirow{4}{*}{1.} & \multirow{4}{*}{ I feel tense or wound up } & Most of the time & $4(8)$ & $5(10)$ \\
\hline & & A lot of the time & $7(14)$ & $5(10)$ \\
\hline & & Time to time, occasionally & $29(58)$ & $30(60)$ \\
\hline & & Not at all & $10(20)$ & $10(20)$ \\
\hline \multirow{4}{*}{2.} & \multirow{4}{*}{ I feel as if I am slowed down } & Nearly all the time & $4(8)$ & $1(2)$ \\
\hline & & Very often & $16(32)$ & $14(28)$ \\
\hline & & Sometimes & $30(60)$ & $26(52)$ \\
\hline & & Not at all & $0(0)$ & $9(18)$ \\
\hline \multirow{4}{*}{3.} & \multirow{4}{*}{ I still enjoy the things I used to enjoy } & Definitely as much & $4(8)$ & $18(36)$ \\
\hline & & Not quite so much & $13(26)$ & $16(32)$ \\
\hline & & Only a little & $12(24)$ & $13(26)$ \\
\hline & & Hardly at all & $21(42)$ & $3(6)$ \\
\hline \multirow{4}{*}{4.} & \multirow{4}{*}{$\begin{array}{l}\text { I get a sort of feeling like 'butterflies' } \\
\text { in the stomach }\end{array}$} & Not at all & $36(72)$ & $44(88)$ \\
\hline & & Occasionally & $10(20)$ & $6(12)$ \\
\hline & & Quite often & $4(8)$ & $0(0)$ \\
\hline & & Very often & $0(0)$ & $0(0)$ \\
\hline \multirow{4}{*}{5.} & \multirow{4}{*}{$\begin{array}{l}\text { I get a sort of frightened feeling as if } \\
\text { something awful is about to happen }\end{array}$} & $\begin{array}{l}\text { Very definitely \& quite } \\
\text { badly }\end{array}$ & $3(6)$ & $5(10)$ \\
\hline & & Yes, but not too badly & $20(40)$ & $14(28)$ \\
\hline & & $\begin{array}{l}\text { A little, but doesn't worry } \\
\text { me }\end{array}$ & $20(40)$ & $20(40)$ \\
\hline & & Not at all & $7(14)$ & $11(22)$ \\
\hline \multirow{4}{*}{6.} & \multirow{4}{*}{ I have lost interest in my appearance } & Definitely & $17(34)$ & $13(26)$ \\
\hline & & $\begin{array}{l}\text { I don't take so much care as } \\
\text { I should }\end{array}$ & $20(40)$ & $9(18)$ \\
\hline & & $\begin{array}{l}\text { I may not take quite as } \\
\text { much care }\end{array}$ & $11(22)$ & $11(22)$ \\
\hline & & $\begin{array}{l}\text { I take just as much care as } \\
\text { ever }\end{array}$ & $2(4)$ & $17(34)$ \\
\hline \multirow{4}{*}{7.} & \multirow{4}{*}{$\begin{array}{l}\text { I can laugh and see the funny side of } \\
\text { things }\end{array}$} & As much as I always could & $5(10)$ & $14(28)$ \\
\hline & & Not quite so much now & $11(22)$ & $16(32)$ \\
\hline & & Definitely not so much now & $16(32)$ & $13(26)$ \\
\hline & & Not at all & $18(36)$ & $7(14)$ \\
\hline \multirow{4}{*}{8.} & \multirow{4}{*}{$\begin{array}{l}\text { I feel restless as if I have to be on the } \\
\text { move }\end{array}$} & Very much indeed & $0(0)$ & $0(0)$ \\
\hline & & Quite a lot & $5(10)$ & $13(26)$ \\
\hline & & Not very much & $33(66)$ & $20(40)$ \\
\hline & & Not at all & $12(24)$ & $17(34)$ \\
\hline \multirow{4}{*}{9.} & \multirow{4}{*}{$\begin{array}{l}\text { Worrying thoughts go through my } \\
\text { mind }\end{array}$} & A great deal of the time & $6(12)$ & $1(2)$ \\
\hline & & A lot of the time & $8(16)$ & $9(18)$ \\
\hline & & $\begin{array}{l}\text { From time to time, but not } \\
\text { too often }\end{array}$ & $11(22)$ & $13(26)$ \\
\hline & & Only occasionally & $25(50)$ & $27(54)$ \\
\hline \multirow{4}{*}{10.} & \multirow{4}{*}{$\begin{array}{l}\text { I look forward with enjoyment to } \\
\text { things }\end{array}$} & As much as I ever did & $2(4)$ & $15(30)$ \\
\hline & & Rather less than I used to & $3(6)$ & $10(20)$ \\
\hline & & $\begin{array}{l}\text { Definitely less than I used } \\
\text { to }\end{array}$ & $22(44)$ & $17(34)$ \\
\hline & & Hardly at all & $23(46)$ & $8(16)$ \\
\hline \multirow{3}{*}{11.} & \multirow{3}{*}{ I feel cheerful } & Not at all & $14(28)$ & $9(18)$ \\
\hline & & Not often & $26(52)$ & $10(20)$ \\
\hline & & Sometimes & $8(16)$ & $16(32)$ \\
\hline
\end{tabular}




\begin{tabular}{|c|c|c|c|c|}
\hline & & Most of the time & $2(4)$ & $15(30)$ \\
\hline \multirow{4}{*}{12.} & \multirow{4}{*}{ I get sudden feelings of panic } & Very often indeed & $0(0)$ & $1(2)$ \\
\hline & & Quite often & $1(2)$ & $16(32)$ \\
\hline & & Not very often & $12(24)$ & $13(26)$ \\
\hline & & Not at all & $37(74)$ & $20(40)$ \\
\hline \multirow{4}{*}{13.} & \multirow{4}{*}{ I can sit at ease and feel relaxed } & Definitely & $1(2)$ & $8(16)$ \\
\hline & & Usually & $16(32)$ & $17(34)$ \\
\hline & & Not often & $29(58)$ & $18(36)$ \\
\hline & & Not at all & $4(8)$ & $7(14)$ \\
\hline \multirow{4}{*}{14.} & \multirow{4}{*}{$\begin{array}{l}\text { I can enjoy a good book or radio or TV } \\
\text { programme }\end{array}$} & Often & $3(6)$ & $18(36)$ \\
\hline & & Sometimes & $13(26)$ & $17(34)$ \\
\hline & & Not often & $18(36)$ & $5(10)$ \\
\hline & & Very seldom & $16(32)$ & $10(20)$ \\
\hline \multirow{3}{*}{15.} & \multirow{3}{*}{ HADS Score- Anxiety } & $0-7$ (Non case) & $34(68)$ & $32(64)$ \\
\hline & & 8-10 (Borderline) & $9(18)$ & $9(18)$ \\
\hline & & $\geq 11$ (Case) & $7(14)$ & $9(18)$ \\
\hline \multirow{3}{*}{16.} & \multirow{3}{*}{ HADS Score- Depression } & $0-7$ (Non case) & $4(8)$ & $22(44)$ \\
\hline & & 8-10 (Borderline) & $5(10)$ & $11(22)$ \\
\hline & & $\geq 11$ (Case) & $41(82)$ & $17(34)$ \\
\hline
\end{tabular}

Figures in the Parenthesis denotes percentage

Descriptive statistics for the variables of the Diabetes Distress Scale (DDS) are presented in Table 3. Based on the DDS scale to assess the level of distress among the diabetic subjects, $2 \%$ of them had distress of clinical attention, $32 \%$ had emotional distress, $8 \%$ of them had physician related distress, $10 \%$ with regimen related distress and about $4 \%$ of them had interpersonal distress.

\begin{tabular}{|c|c|c|c|c|c|c|c|}
\hline \multirow[b]{2}{*}{$\begin{array}{l}\text { Sl. } \\
\text { No. }\end{array}$} & \multirow[b]{2}{*}{$\begin{array}{l}\text { Problem } \\
\text { Areas }\end{array}$} & \multicolumn{6}{|c|}{ Degree of Distress in Diabetics n (\%) } \\
\hline & & $\begin{array}{l}\text { Not a } \\
\text { Problem }\end{array}$ & $\begin{array}{c}\text { Slight } \\
\text { Problem }\end{array}$ & $\begin{array}{c}\text { Moderate } \\
\text { Problem }\end{array}$ & $\begin{array}{l}\text { Somewhat } \\
\text { Serious } \\
\text { Problem }\end{array}$ & $\begin{array}{l}\text { Serious } \\
\text { Problem }\end{array}$ & $\begin{array}{c}\text { Very } \\
\text { Serious } \\
\text { Problem } \\
\end{array}$ \\
\hline 1. & $\begin{array}{l}\text { Feeling that diabetes is taking up } \\
\text { too much of my mental and } \\
\text { physical energy everyday }\end{array}$ & $5(10)$ & $19(38)$ & $18(36)$ & $6(12)$ & $1(2)$ & $1(2)$ \\
\hline 2. & $\begin{array}{l}\text { Feeling that my doctor doesn't } \\
\text { know enough about diabetes and } \\
\text { diabetes care }\end{array}$ & $45(90)$ & $3(6)$ & $1(2)$ & $0(0)$ & $0(0)$ & $1(2)$ \\
\hline 3. & $\begin{array}{l}\text { Feeling angry, scared and/or } \\
\text { depressed when I think about } \\
\text { living with diabetes }\end{array}$ & $5(10)$ & $25(50)$ & $14(28)$ & $5(10)$ & $1(2)$ & $0(0)$ \\
\hline 4. & $\begin{array}{l}\text { Feeling that my doctor doesn't } \\
\text { give me clear enough directions } \\
\text { on how to manage my diabetes }\end{array}$ & $43(86)$ & $2(4)$ & $0(0)$ & $0(0)$ & $2(4)$ & $3(6)$ \\
\hline 5. & $\begin{array}{l}\text { Feeling that I am not testing my } \\
\text { blood sugars frequently enough }\end{array}$ & $36(72)$ & $10(20)$ & $1(2)$ & $1(2)$ & $1(2)$ & $1(2)$ \\
\hline 6. & $\begin{array}{l}\text { Feeling that I am often failing } \\
\text { with my diabetes routine }\end{array}$ & $13(26)$ & $23(46)$ & $5(10)$ & $6(12)$ & $3(6)$ & $0(0)$ \\
\hline 7. & $\begin{array}{l}\text { Feeling that friends or family are } \\
\text { not supportive enough of self- } \\
\text { care efforts }\end{array}$ & $44(88)$ & $5(10)$ & $1(2)$ & $0(0)$ & $0(0)$ & $0(0)$ \\
\hline 8. & $\begin{array}{l}\text { Feeling that diabetes controls my } \\
\text { life }\end{array}$ & $4(8)$ & $11(22)$ & $16(32)$ & $11(22)$ & $5(10)$ & $3(6)$ \\
\hline 9. & $\begin{array}{l}\text { Feeling that my doctor doesn't } \\
\text { take my concerns seriously } \\
\text { enough }\end{array}$ & $43(86)$ & $2(4)$ & $1(2)$ & $1(2)$ & $2(4)$ & $1(2)$ \\
\hline 10. & $\begin{array}{l}\text { Not feeling confident in my day- } \\
\text { to-day ability to manage diabetes }\end{array}$ & $10(20)$ & $26(32)$ & $11(22)$ & $1(2)$ & $2(4)$ & $0(0)$ \\
\hline 11. & $\begin{array}{l}\text { Feeling that I will end up with } \\
\text { serious long-term complications, } \\
\text { no matter what I do }\end{array}$ & $4(8)$ & $35(70)$ & $11(22)$ & $0(0)$ & $0(0)$ & $0(0)$ \\
\hline 12. & $\begin{array}{l}\text { Feeling that I am not sticking } \\
\text { closely enough to a good meal } \\
\text { plan }\end{array}$ & $18(36)$ & $15(30)$ & $6(12)$ & $7(14)$ & $3(6)$ & $1(2)$ \\
\hline 13. & $\begin{array}{l}\text { Feeling that friends or family } \\
\text { don't appreciate how difficult } \\
\text { living with diabetes can be }\end{array}$ & $44(88)$ & $4(8)$ & $2(4)$ & $0(0)$ & $0(0)$ & $0(0)$ \\
\hline 14. & Feeling overwhelmed by the & $11(22)$ & $11(22)$ & $14(28)$ & $9(18)$ & $4(8)$ & $1(2)$ \\
\hline
\end{tabular}




\begin{tabular}{|c|c|c|c|c|c|c|c|}
\hline & demands of living with diabetes & & & & & & \\
\hline 15. & $\begin{array}{l}\text { Feeling that I don't have a doctor } \\
\text { who I can see regularly enough } \\
\text { about diabetes }\end{array}$ & $34(68)$ & $8(16)$ & $4(8)$ & $2(4)$ & $1(2)$ & $1(2)$ \\
\hline 16. & $\begin{array}{l}\text { Not feeling motivated to keep up } \\
\text { my diabetes self-management }\end{array}$ & $6(12)$ & $32(64)$ & $7(14)$ & $3(6)$ & $2(4)$ & $0(0)$ \\
\hline 17. & $\begin{array}{l}\text { Feeling that friends or family } \\
\text { don't give me the emotional } \\
\text { support that I would like }\end{array}$ & $45(90)$ & $3(6)$ & $1(2)$ & $1(2)$ & $0(0)$ & $0(0)$ \\
\hline
\end{tabular}

Table 3: The Diabetes Distress Scale [DDS]

DDS mean item score $(\geq 3)$

\begin{tabular}{|l|c|c|}
\hline \multirow{4}{*}{ DDS mean item score $(\geq 3)$} & Total score & $1(2)$ \\
\cline { 2 - 3 } & Emotional burden & $16(32)$ \\
\cline { 2 - 3 } & Physician-related distress & $4(8)$ \\
\cline { 2 - 3 } & Regimen-related distress & $5(10)$ \\
\cline { 2 - 3 } & Interpersonal distress & $2(4)$ \\
\hline
\end{tabular}

Figures in the Parenthesis denotes percentage.

Descriptive statistics for the variables of the Summary of Diabetes Self Care Activities Scale (SDSCA Scale) are presented in Table 4.

\begin{tabular}{|c|c|c|c|c|c|c|c|c|c|}
\hline \multirow{2}{*}{$\begin{array}{l}\text { Sl. } \\
\text { No. }\end{array}$} & \multirow[t]{2}{*}{ Self-Care Activities } & \multicolumn{8}{|c|}{$\begin{array}{l}\text { No of Days/Week the Activity followed by Diabetics-n } \\
\text { (\%) }\end{array}$} \\
\hline & & $\mathbf{0}$ & 1 & 2 & 3 & 4 & 5 & 6 & 7 \\
\hline \multicolumn{10}{|l|}{ Diet: } \\
\hline 1. & $\begin{array}{l}\text { On average, over the past month, how many days per week } \\
\text { have you followed your eating plan? }\end{array}$ & $3(6)$ & $2(4)$ & $\begin{array}{c}8 \\
(16)\end{array}$ & $\begin{array}{c}10 \\
(20)\end{array}$ & $\begin{array}{c}5 \\
(10)\end{array}$ & $\begin{array}{c}8 \\
(16)\end{array}$ & $\begin{array}{c}6 \\
(12)\end{array}$ & $\begin{array}{c}8 \\
(16)\end{array}$ \\
\hline 2. & $\begin{array}{l}\text { On how many of the last seven days did you eat five or } \\
\text { more servings of fruits and vegetables? }\end{array}$ & $2(4)$ & $\begin{array}{c}10 \\
(20) \\
\end{array}$ & $\begin{array}{c}12 \\
(24) \\
\end{array}$ & $\begin{array}{c}15 \\
(30)\end{array}$ & $\begin{array}{c}6 \\
(12) \\
\end{array}$ & $3(6)$ & $\begin{array}{c}2 \\
(4)\end{array}$ & $0(0)$ \\
\hline 3. & $\begin{array}{l}\text { On how many of the last seven days did you eat high fat } \\
\text { foods such as red meat or full-fat dairy products? }\end{array}$ & $\begin{array}{c}9 \\
(18)\end{array}$ & $\begin{array}{c}27 \\
(54)\end{array}$ & $\begin{array}{c}7 \\
(14)\end{array}$ & $1(2)$ & $\begin{array}{c}4 \\
(8)\end{array}$ & $2(4)$ & $\begin{array}{c}0 \\
(0)\end{array}$ & $0(0)$ \\
\hline 4. & $\begin{array}{l}\text { On how many of the last seven days did you space } \\
\text { carbohydrates evenly through the day? }\end{array}$ & $1(2)$ & $\begin{array}{c}5 \\
(10)\end{array}$ & $4(8)$ & $\begin{array}{c}7 \\
(14)\end{array}$ & $\begin{array}{c}7 \\
(14)\end{array}$ & $\begin{array}{c}15 \\
(30)\end{array}$ & $\begin{array}{c}7 \\
(14)\end{array}$ & $4(8)$ \\
\hline 5. & $\begin{array}{l}\text { On how many of the last seven days have you followed a } \\
\text { healthful eating plan? }\end{array}$ & $3(6)$ & $4(8)$ & $\begin{array}{c}7 \\
(14)\end{array}$ & $\begin{array}{c}17 \\
(34)\end{array}$ & $\begin{array}{c}8 \\
(16)\end{array}$ & $\begin{array}{c}7 \\
(14)\end{array}$ & $\begin{array}{c}4 \\
(8)\end{array}$ & $0(0)$ \\
\hline \multicolumn{10}{|c|}{ Exercise: } \\
\hline 1. & $\begin{array}{l}\text { On how many of the last seven days did you participate in } \\
\text { at least } 30 \text { minutes of physical activity }\end{array}$ & $\begin{array}{c}13 \\
(26)\end{array}$ & $4(8)$ & $2(4)$ & $\begin{array}{c}5 \\
(10) \\
\end{array}$ & $\begin{array}{c}4 \\
(8)\end{array}$ & $\begin{array}{c}5 \\
(10) \\
\end{array}$ & $\begin{array}{c}7 \\
(14)\end{array}$ & $\begin{array}{c}10 \\
(20)\end{array}$ \\
\hline 2. & $\begin{array}{l}\text { On how many of the last seven days did you participate in } \\
\text { a specific exercise session other than what you do around } \\
\text { the house or as part of your work }\end{array}$ & $\begin{array}{c}22 \\
(44)\end{array}$ & $2(4)$ & $2(4)$ & $3(6)$ & $\begin{array}{c}5 \\
(10)\end{array}$ & $3(6)$ & $\begin{array}{c}5 \\
(10)\end{array}$ & $\begin{array}{c}8 \\
(16)\end{array}$ \\
\hline \multicolumn{10}{|c|}{ Blood Sugar Testing: } \\
\hline 1. & $\begin{array}{l}\text { On how many of the last seven days did you test your } \\
\text { blood sugar? }\end{array}$ & $\begin{array}{c}20 \\
(40)\end{array}$ & $\begin{array}{c}9 \\
(18)\end{array}$ & $\begin{array}{c}8 \\
(16)\end{array}$ & $\begin{array}{c}11 \\
(22)\end{array}$ & $\begin{array}{c}1 \\
(2)\end{array}$ & $0(0)$ & $\begin{array}{c}1 \\
(2)\end{array}$ & $0(0)$ \\
\hline 2. & $\begin{array}{l}\text { On how many of the last seven days did you test your } \\
\text { blood sugar the number of times recommended by your } \\
\text { healthcare provider? }\end{array}$ & $\begin{array}{c}23 \\
(46)\end{array}$ & $\begin{array}{c}6 \\
(12)\end{array}$ & $\begin{array}{c}5 \\
(10)\end{array}$ & $\begin{array}{c}11 \\
(22)\end{array}$ & $\begin{array}{c}5 \\
(10)\end{array}$ & $0(0)$ & $\begin{array}{c}0 \\
(0)\end{array}$ & $0(0)$ \\
\hline \multicolumn{10}{|c|}{ Foot Care: } \\
\hline 1. & $\begin{array}{l}\text { On how many of the last seven days did you check your } \\
\text { feet? }\end{array}$ & $\begin{array}{c}15 \\
(30)\end{array}$ & $\begin{array}{c}9 \\
(18)\end{array}$ & $4(8)$ & $3(6)$ & $\begin{array}{c}6 \\
(12)\end{array}$ & $2(4)$ & $\begin{array}{c}3 \\
(6)\end{array}$ & $\begin{array}{c}8 \\
(16)\end{array}$ \\
\hline 2. & $\begin{array}{l}\text { On how many of the last seven days did you inspect the } \\
\text { inside of your shoes? }\end{array}$ & $\begin{array}{c}33 \\
(66)\end{array}$ & $2(4)$ & $2(4)$ & $3(6)$ & $\begin{array}{c}3 \\
(6) \\
\end{array}$ & $0(0)$ & $\begin{array}{c}5 \\
(10)\end{array}$ & $2(4)$ \\
\hline
\end{tabular}

Figures in the Parenthesis denotes percentage

The correlation coefficients of anxiety and depression levels between the diabetic and the normal subjects using unpaired t test is given in Table 4. The components of HADS enquiring about the levels of anxiety and depression showed that the diabetic population had an increased prevalence of depression than anxiety $(\mathrm{p}<0.05)$. The correlation coefficient for anxiety and depression among the Diabetics and the NonDiabetics are 0.628 and $0.000(\mathrm{p}<0.05)$ using the MannWhitney test [Table 5]. 


\begin{tabular}{|l|c|}
\hline \multicolumn{1}{|c|}{ Variable } & $\begin{array}{c}\text { Unpaired t Test } \\
\text { (P value) }\end{array}$ \\
\hline I feel tense or wound up & 1.000 \\
\hline I feel as if I am slowed down & 0.015 \\
\hline I still enjoy the things I used to enjoy & 0.000 \\
\hline $\begin{array}{l}\text { I get a sort of feeling like 'butterflies' in } \\
\text { the stomach }\end{array}$ & 0.019 \\
\hline $\begin{array}{l}\text { I get a sort of frightened feeling as if } \\
\text { something awful is about to happen }\end{array}$ & 0.490 \\
\hline I have lost interest in my appearance & 0.002 \\
\hline $\begin{array}{l}\text { I can laugh and see the funny side of } \\
\text { things }\end{array}$ & 0.001 \\
\hline $\begin{array}{l}\text { I feel restless as if I have to be on the } \\
\text { move }\end{array}$ & 0.661 \\
\hline Worrying thoughts go through my mind & 0.257 \\
\hline I look forward with enjoyment to things & 0.000 \\
\hline I feel cheerful & 0.000 \\
\hline I get sudden feelings of panic & 0.000 \\
\hline I can sit at ease and feel relaxed & 0.136 \\
\hline $\begin{array}{l}\text { I can enjoy a good book or radio or TV } \\
\text { programme }\end{array}$ & 0.000 \\
\hline HADS Score- Anxiety & 0.601 \\
\hline HADS Score-Depression & 0.000 \\
\hline Table 5: Correlation Coefficients of Anxiety and Depression \\
\hline
\end{tabular}

\section{DISCUSSION}

Factors affecting the quality of life of people with Diabetes Mellitus are varied, one among which is the psychiatric comorbidities associated with Diabetes Mellitus. In the present study in which the socio-demographic profile of the two groups (Type 2 Diabetes Mellitus and normal subjects) is comparable, the level of depression is higher than that of anxiety in the diabetic population when compared with the normal subjects.

In this study, forty one out of fifty $(82 \%)$ diabetics were found to have depression based on the HADS scale. Whereas according to a meta-analysis conducted by Anderson RJ et al ${ }^{13}$ and DeGroot $\mathrm{M}$ et $\mathrm{al}^{14}$, the prevalence of major depression among adults with diabetes was found to be $11 \%$ and clinically relevant depression was 31\% respectively.

The relationship between depression and diabetes appears to be bi-directional, i.e. those with diabetes are at increased risk for developing depression; and conversely, those with depression are at increased risk for developing diabetes. ${ }^{15}$ A substantial, positive and significant association exists between the incidence of diabetes and untreated depression among adults 55 years of age or older. ${ }^{16}$ For the people diagnosed with diabetes, the addition of depression serves to increase symptom burden, diabetes-related complications, unemployment, work-related disability and healthcare costs. ${ }^{17}$ Individuals with both diabetes and depression have a 2.3 times greater risk of early mortality than do non-depressed people with diabetes. ${ }^{18}$ Co-morbid depression is associated with poorer control of blood glucose levels, increased incidence of diabetes complications and impaired engagement in self-management including ability to take medications as prescribed, follow treatment plans and actively engage in self-care behaviors. ${ }^{19} \mathrm{~A}$ study conducted by Fischer $\mathrm{L}$ et $\mathrm{al}^{20}$ revealed that people with diabetes exhibit relatively high rates of diabetes-specific distress, affective and anxiety disorders. People with diabetes had a $20 \%$ higher prevalence of lifetime diagnosis of anxiety than those without diabetes. ${ }^{21}$ whereas in this study the prevalence of anxiety among diabetics is found to be about 34\% (Seventeen out of fifty patients).

Generalized Anxiety Disorder (GAD) appears to be the most common anxiety disorder in patients with diabetes with reviews suggesting point-prevalence rates between 13 and $14 \% .22$ This increased prevalence may be related to fears of self-injecting or self-testing. Fear of hypoglycaemia or low blood sugars which is often associated with unpleasant symptoms such as tremors, profuse sweating, cognitive dysfunction and irritability is another common fear in patients taking insulin. ${ }^{23}$ Taken together these lead to suboptimal outcomes, increased medical co-morbidity and diabetes-related mortality. Hence, diabetes self-management is crucial to management of the disease and has been shown to mitigate future complications, reduce risk of comorbidities, and improve the overall health. Emotional wellbeing and decrease of psychiatric co-morbidities such as depression or anxiety would decrease the patient's distress, strain and would increase one's confidence which would result in better self-care, quality of life and relation of family. Family behaviours such as communication, life styles and dynamic of family interaction could influence the health outcome such as depression, anxiety and perception of quality of life. ${ }^{24}$

In a study conducted at Dhaka by Islam et al have reported that the overall diabetic distress was $48.5 \%$, of which $22.4 \%$ were having high distress. ${ }^{25}$ In an another study at Malaysia, it was reported that $19.6 \%$ had moderate distress. ${ }^{26}$ In this study, 32\% had emotional distress. A study conducted at Karnataka, India by Rajasekharan et al reported out that self-care practices were found to be unsatisfactory in all aspects except blood sugar monitoring. ${ }^{27}$ But this study showed that the participants were very poor in Diabetes SelfCare Activities such as diet, exercise, blood sugar testing and foot care. Since the studied population was limited to single centre, similar studies in multiple centres may be carried out in different geographical and different socioeconomic groups before arriving at valid conclusions.

\section{LIMITATIONS}

This study was conducted in a single area and is a single centred study.

\section{ACKNOWLEDGEMENT}

The authors gratefully acknowledge the Indian Council of Medical Research [ICMR] for the approval of this study to the 2nd author under Short Term Studentship. The authors also acknowledge the authorities of Chennai Medical College Hospital and Research Centre to conduct this study.

\section{CONCLUSION}

1. On comparing the diabetics and the normal individuals, the diabetic population had increased levels of depression than anxiety which was found to be statistically significant, the prevalence of depression was found to be higher in the diabetic subjects $(82 \%)$ when compared with the normal subjects (34\%) and this difference was found to be statistically significant using 
the unpaired t test, Pearson Chi-Square test and the Mann-Whitney test $(\mathrm{p}<0.05)$.

2. Based on the Diabetes Distress Scale, $32 \%$ had emotional distress and most of them had an emotional distress rather than the physician related distress, regimen related distress or interpersonal distress.

3. Based on the Summary of Diabetes Self Care Activities Scale, most of the diabetics did not opt for a strict diet or exercise plan, blood sugar testing or foot care and $40 \%$ of the diabetic subjects sometimes forget to take medicine.

\section{REFERENCES}

1. De Grauw WJ, van de Lisdonk EH, Behr RR, et al. The impact of type 2 diabetes mellitus on daily functioning. Family Practice 1999;16(2):133-9.

2. Jacobson AM, de Groot M, Samson JA. The effects of psychiatric disorders and symptoms on quality of life in patients with type 1 and type 2 diabetes mellitus. Qual Life Res 1997;6(1):11-20.

3. Omer Saatcioglu, Feryal Cam Celikel, Faruk Kutluturk, et al. Disability and quality of life in patients with type 2 diabetes mellitus. Anatol J Clin Investig 2008;2(3):10612.

4. Cox DJ, Gonder-Frederick L. Major developments in behavioural diabetes research. J Consult Clin Psychol 1992;60(4):628-38.

5. Jeffrey S Gonzalez, Sabrina A Esbitt, Havah E Schneider, et al. Psychological issues in adults with type 2 diabetes. A behavioural medicine perspective. Springer 2011;73122.

6. Peyrot M, Rubin RR, Lauritzen $\mathrm{T}$, et al. Psychosocial problems and barriers to improved diabetes management: results of the cross-national diabetes attitudes, wishes and needs (DAWN) study. Diabet Med 2005;22(10):1379-85.

7. Lustman PJ, Anderson RJ, Freedland KE, et al. Depression and poor glycaemic control: a meta-analytic review of the literature. Diabetes Care 2000;23(7):934-42.

8. Pita R, Fotakopoulou O, Kiosseoglou G, et al. Depression, quality of life and diabetes mellitus. Hippokratia 2002;6:S44-7.

9. Morisky DE, Green LW, Levine DM. Concurrent and predictive validity of a self-reported measure of medication adherence. Med Care 1986;24(1):67-74.

10. Bjelland I, Dahl AA, Haug TT, et al. The validity of the hospital anxiety and depression scale an updated literature review. J Psychosom 2002;52(2):69-77.

11. William H Polonsky, Lawrence Fisher, Earles J, et al. Assessing psychosocial distress in diabetes-development of the diabetes distress scale. Diabetes Care 2005;28(3):626-31.

12. Deborah J Toobert, Sarah E Hampson, Russell E Glasgow. The summary of diabetes self-care activities measureresults from 7 studies and a revised scale. Diabetes Care 2000;23(7):943-50.
13. Anderson RJ, Freedland KE, Clouse RE, et al. The prevalence of comorbid depression in adults with diabetes: a meta-analysis. Diabetes care 2001;24(6):1069-78.

14. DeGroot M, Kushnick M, Doyle T, et al. Depression among adults with diabetes: prevalence, impact and treatment options. Diabetes Spectrum 2010;23(1):15-8.

15. Renn BN, Feliciano L, Segal DL. The bidirectional relationship of depression and diabetes: a systematic review. Clinical psychology review 2011;31(8):1239-46.

16. Campayo A, de Jonge P, Roy JF, et al. ZARADEMP project. Depressive disorder and incident diabetes mellitus: the effect of characteristics of depression. Am J Psychiatry 2010;167(5):580-8.

17. Ciechanowski PS, Katon WJ, Russo JE. Depression and diabetes: impact of depressive symptoms on adherence, function, and costs. Arch Intern Med 2000;160(21):3278-85.

18. Katon W, Lyles CR, Parker MM, et al. Association of depression with increased risk of dementia in patients with type 2 diabetes: the diabetes and aging study. Arch General Psychiatry 2012;69(4):410-7.

19. Lin EH, Katon W, Von Korff M, et al. Relationship of depression and diabetes self-care, medication adherence, and preventive care. Diabetes care 2004;27(9):2154-60.

20. Fisher L, Skaff MM, Mullan JT, et al. A longitudinal study of affective and anxiety disorders, depressive affect and diabetes distress in adults with type 2 diabetes. Diabet Med 2008;25(9):1096-101.

21. Li C, Barker L, Ford ES, et al. Diabetes and anxiety in US adults: findings from the 2006 behavioural risk factor surveillance system. Diabetic Medicine 2008;25(7):87881.

22. Grigsby AB, Anderson RJ, Freedland KE, et al. Prevalence of anxiety in adults with diabetes: a systematic review. Journal of Psychosomatic Research 2002;53(6):1053-60.

23. Weinger K, Lee J. Psychosocial and psychiatric challenges of diabetes mellitus. Nurs Clin North Am 2006;41(4):667-80.

24. Cole I, Chesla CA. Interventions for the family with diabetes. Nurs Clin North Am 2006;41(4):625-39.

25. Islam MR, Karim MR, Habib SH, et al. Diabetes distress among type 2 diabetic patients. Int J Med Biomed Res 2013;2(2):113-24.

26. Boon-How Chew, Sherina Mohd-Sidik, Sazlina ShariffGhazali. Negative effects of diabetes-related distress on health-related quality of life: an evaluation among the adult patients with type 2 diabetes mellitus in three primary healthcare clinics in Malaysia. Health Qual Life Outcomes 2015;13:187.

27. Rajasekharan D, Kulkarni V, Unnikrishnan B, et al. Selfcare activities among patients with diabetes attending a tertiary care hospital in Mangalore, Karnataka, India. Ann Med Health Sci Res 2015;5(1):59-64. 